\title{
UNITED NATIONS PUBLICATIONS
}

covers questions dealing with the African region on many subjects. For a detailed picture of the UN publishing programme send for our catalogues, available free of charge. .

\section{STANDING ORDER SERVICE GUIDE} UN OFFICIAL RECORDS MICROFICHE PRICE LIST

UN PUBLICATIONS IN PRINT STANOMNG ORDER . 


\title{
Language, Society, and Paleoculture
}

\begin{abstract}
ESSAYS BY EDGAR C. POLOMÉ
Edited by Anwar S. Dil. These 18 essays treat three aspects of a leading sociolinguist's research on language, culture, and society: the languages of eastern and central Africa, the process of creolization, and linguistic paleontology and the reconstruction of proto-cultures. Part I offers a sociolinguistic perspective on the language policies of Zaire and Tanzania. Part II contains papers on Swahili, tracing its development in Zaire and dealing with its modernization in Tanzania. Part III explores the theory of creolization. Part IV concerns the use of lexical data to probe the cultural and religious past of the Indo-Europeans and the Bantus. This is the 19th volume in the series Language Science and National Development. \$20.00
\end{abstract}

Order from your bookstore, please

\section{Stanford University Press}

\section{The Highest Stage of White Supremacy}

The Origins of Segregation in South Africa and the American South JOHNW. CELL

Analyses the origins of segregation as a specific stage in the evolution of white supremacy in South Africa and the American South. Professor Cell argues that segregationalism was a distinct system and ideology of race-class stratification, closely associated with urbanisation, industrialisation, and modern processes of state and party formation.

E20.00 net

\section{Black Soul White Artifact}

Fanon's Clinical Psychology and Social Theory

\section{JOCK MCCULLOCH}

Examines all Frantz Fanon's writings - not only The Wretched of the Earth, Black Skin White Masks and Toward the African Revolution, but also a number of clinical psychiatric studies written in Algeria and Tunisia which change the established view of his work. Dr McCulloch raises important questions about political control and the relationship between personality and politics.

E22.50 net

\section{CAMBRIDGE UNIVERSITY PRESS}




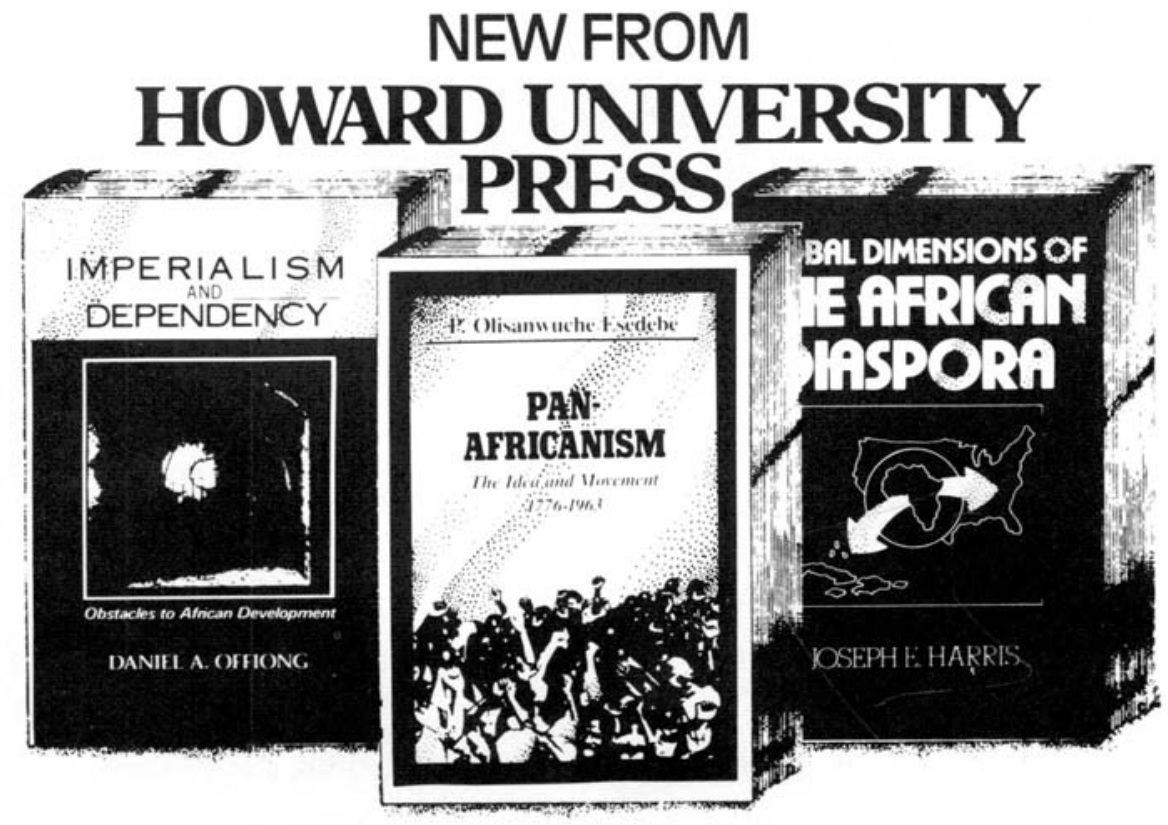

crompingugers or

Arich ouspon

edited by Joseph E. Harris

Offers the best and most recent data and ideas on the dispersal, adaptation and return to Africa of descendant Africans. 0-88258-022-1 $\$ 19.95$ cloth

\section{PNy-Ariconyen}

by P. Olisanwuche Esedebe

Assesses the hostility of European colonial. ism toward the leaders and philosophy of Pan-Africanism.

$0-88258 \cdot 124-4$

$0-88258 \cdot 125 \cdot 2$

\section{minculs AND DEPENDENCY:}

Obstacles to African Development by Daniel A. Offiong

Discusses the relationship between Africa (and other third world models) and the United States, Britain and Russia.

0-88258-126-0

0-88258-127-9

\section{$\$ 12.95$ cloth}

6.9s paper

s12.9s cloth

\$ 6.9s paper
Townso THE

DECOLONILTION OF AFRICAN

LTERATURE,

volume I

by Chinweizu,

onwuchekwa Jemie and

inechukwu Madubuike

Liberates African literature from the

narrowness of colonial oppression.

0-88258-122-8

$0-88258-123-6$

$\$ 12.95$ cloth

$\$ 7.95$ paper

\section{TRAnsFonewation}

AND RESILIENCY IN

Araica

edited by

Pearl T. Robinson and

Elliott $P$. Skinner

Examines, from an afrocentric perspective, social, political and cultural change in modern Africa.

$0.88258 .054 \cdot x$

514.95 cloth

\section{AI HOWARD UNIVERSTYY PRESS}

Howard University Press/2900 Van Ness Street. N.W. Washington, D.C. 20008, (202) 686-6696 


\section{Minerva}

A REVIEW OF SCIENCE, LEARNING

AND POLICY

Editor: Edward Shils

Contents of Volume XIX Number 2

ARTICLES

Ivory Towers? Universities in Sri Lanka Dennis Austin

The American Private Philanthropic Foundation and the Public

Sphere 1890-1930 Barry D. Karl and Stanley N. Katz

Remarks on the History of Foundations and their Role in the

Promotion of Learning Helmut Coing

The Indian University: Academic Standards and the Pursuit of Equality André Béteille

\section{REPORTS AND DOCUMENTS}

A Critical Review of the Statement of Affrmative Action in the 1980 s of the United States Commission on Civil Rights John H. Bunzel

BOOK REVIEWS

Reviews by Robert Fox, Terry Shinn

\section{Minerva}

is published quarterly

Annual subscription : $£ 18.00 / \$ 45.00$

Single copy: $£ 5.00 / \$ 12.00$

\section{Minerva}

59 ST MARTIN'S LANE, LONDON WC 2 N 4JS 


\section{THE JOURNAL OF MODERN AFRICAN STUDIES}

The Journal offers a quarterly survey of politics, economics, and related topics in contemporary Africa.

The main emphasis is upon the peoples and policies, the problems and progress of this dynamic and disparate continent; upon the many societies that are evolving rather than the essential characteristics of the old; upon the present, not on the more distant past. The best current work is sought from specialists in different academic disciplines, whose contributions can illuminate and crossfertilise one another.

The Journal seeks to promote a deeper understanding of what is happening in Africa today. It is intended for both the political scientist and the practical politician, the administrator and the advocate, the economist and the educator, the banker and the business man, the diplomat and the technocrat, the civil servant and the nationalist leader. All have something to contribute to these pages and, it is hoped, much to learn from them.

Editorial policy avoids commitment to any political viewpoint or ideology, whether imperialism, pan-Africanism, capitalism, socialism, or nationalism. Such concepts, however, have relevance to the modern African situation, and merit serious discussion, often from several different points of view, in order that controversial issues may be fairly examined.

(C) Cambridge University Press 1983

Contributors of accepted articles will be asked to assign their copyright, on certain conditions, to Cambridge University Press, to help protect their material, particularly in the U.S.A.

\section{Copying}

This journal is registered with the Copyright Clearance Center, 2 I Congress St., Salem, Mass. or970. Organisations in the U.S.A. who are also registered with C.C.C. may therefore copy material (beyond the limits permitted by sections 107 and 108 of U.S. copyright law) subject to payment to C.C.C. of the per copy fee of \$05.00. Code $0022-278 x / 83 / 2828-0001$ \$05.00. This consent does not extend to multiple copying for promotional or commercial purposes.

ISI Tear Service, 350 I Market Street, Philadelphia, Pennsylvania 19104, U.S.A., is authorised to supply single copies of separate articles for private use only.

For all other use, permission should be sought from the Cambridge or New York offices of the Cambridge University Press. 


\section{CAMBRIDGE UNIVERSITY PRESS}

The Pitt Building, Trumpington Street, Cambridge CB2 1RP

32 East 57 th Street,

New York, N.Y. 10022

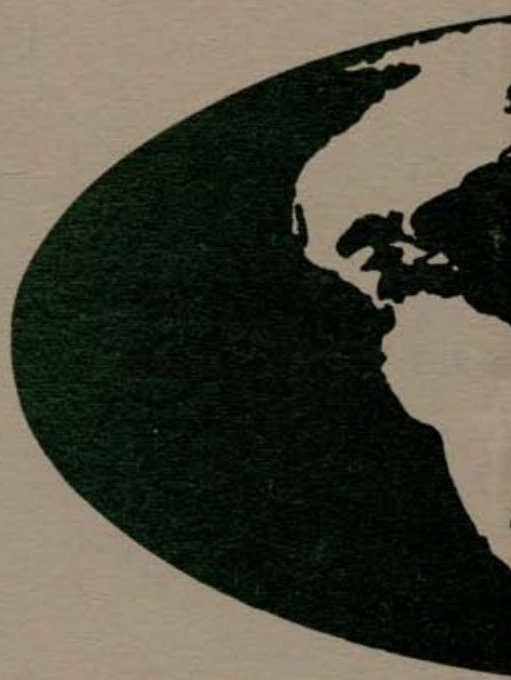

C Cambridge University Press 1983 